\title{
Distribution of Glycerol Dialkyl Glycerol Tetraethers (GDGTs) in Microbial Mats From Holocene and Miocene Sabkha Sediments
}

\author{
Benjamin Petrick ${ }^{*}$, Lars Reuning $^{2,3}$ and Alfredo Martínez-García ${ }^{1}$ \\ ${ }^{1}$ Climate Geochemistry Department, Max Planck Institute for Chemistry, Mainz, Germany, ${ }^{2}$ Institute for Geosciences, \\ Kiel University, Kiel, Germany, ${ }^{3}$ Geological Institute, RWTH Aachen University, Aachen, Germany
}

Sabkhas are important settings for understanding early earth biological environments, and the algal mats associated with them are thought to be potential source rocks for hydrocarbon production. In this study we compare the sedimentological facies and distribution of branched, and isoprenoid glycerol dialkyl glycerol tetraethers (GDGTs) in modern and mid-Holocene sabkha sediments from Abu Dhabi with well-preserved Miocene (12-13 Ma) sabkha sediments recently recovered at IODP site U1464 off

OPEN ACCESS

Edited by: Francien Peterse, Utrecht University, Netherlands

Reviewed by:

Xiao-Lei Liu, The University of Oklahoma,

United States

Florence Schubotz, University of Bremen, Germany

*Correspondence: Benjamin Petrick

b.petrick@mpic.de

Specialty section: This article was submitted to Biogeoscience, a section of the journal Frontiers in Earth Science

Received: 20 May 2019 Accepted: 06 November 2019 Published: 04 December 2019

Citation:

Petrick $B$, Reuning $L$ and Martínez-García A (2019) Distribution of Glycerol Dialkyl Glycerol Tetraethers (GDGTs) in Microbial Mats From Holocene and Miocene Sabkha

Sediments. Front. Earth Sci. 7:310. doi: 10.3389/feart.2019.00310 the north coast of Australia. We show that the facies of the Miocene sediments is very similar to Holocene and modern sabkhas. Furthermore, we show that there are distinct patterns of isoprenoid GDGT distributions in the modern sabkha and that these patterns are well preserved in both the buried Holocene and the Miocene algal mats. The sabkha sediments analyzed are characterized by high \%GDGT-0 and methane index, dominance of branched GDGTs over crenarchaeol (high BIT index), an unusual distribution of isoprenoid GDGTs 1-3, and also low abundance of archeol. The distribution of branched GDGT differs between modern and Miocene sabkhas and is similar in Miocene sabkha and non-sabkha sediments suggesting that they may be of limited use to distinguish paleo-sabkha sediments. Overall, isoprenoid GDGT distributions appear to be different from those found in modern soils, lakes and marine sediments, as well as from those found in Miocene shallow water sediments right below the sabkha, therefore they could be used in combination with facies analysis to identify paleo-sabkha environments in sedimentary sequences.

Keywords: sabkha, GDGT, GDGT lipids, Miocene, biogeochemistry

\section{INTRODUCTION}

In the modern day, marine coastal sabkhas develop as parallel facies belts, where seawater inundates shallow sedimentary basins under arid conditions. Well-known sabkha environments include the Arabian Peninsula (Evans et al., 1969; Wood and Wolfe, 1969; Kenig et al., 1990) and Shark Bay, Australia (Davies, 1970). In a strict sense, the term "coastal sabkha" refers to an evaporitic mudflat, where evaporite minerals form in the carbonate or siliciclastic matrix of the supratidal zone. Defined as such, the sabkha is a diagenetic overprint, rather than a depositional system. In a 
broader sense (which is used for this study), the complete depositional system of a sabkha includes not only the supratidal but also the subtidal and intertidal zone. Sabkhas form ideal environments for the study of sedimentological and biologic development under extreme conditions. They are thought to be analogs for early earth environments, as most modern day stromatolites are found in sabkha like environments (Davies, 1970; Suosaari et al., 2016). These high salinity shallow water environments are also thought to have similarities with early Mars environments and therefore constitute important study sites for testing methods of identification of life on other planets (Edwards et al., 2010; Chan et al., 2011). Microbial mats accumulate in the intertidal zone, where the arid environment is too hostile for grazing animals such as gastropods (Strohmenger et al., 2011) and ultimately form important source rocks for the production of petroleum (Kenig et al., 1990).

Sabkha derived sediments have been identified throughout Earth's history using primarily sedimentary or mineral signatures (Curtis et al., 1963; Maliński et al., 2009; Lugli et al., 2015). Biomarker signatures have also been studied, but most of the studies have focused on a limited set of compounds using only modern or Holocene sediments (Kenig et al., 1990; Maliński et al., 2009; Słowakiewicz et al., 2016). These studies have suggested a number of potentially distinctive biomarkers including, for example, $\mathrm{C}_{20}, \mathrm{C}_{21}$, and $\mathrm{C}_{22}$ highly branched isoprenoids (Kenig et al., 1990; Maliński et al., 2009).

Glycerol dialkyl glycerol tetraethers (GDGTs) are membrane lipids synthetized by different groups of archaea, and have been found in a wide range of aquatic and terrestrial environmental settings (Schouten et al., 2013). To our knowledge, only one study has categorized the distribution of GDGTs in microbial mats from sabkha environments (Słowakiewicz et al., 2016). This study investigated the abundance of GDGTs in a single modern microbacterial mat from Qatar to a depth of $4 \mathrm{~cm}$, and showed that the compound GDGT-0 dominated the distribution, with relative low concentrations of crenarchaeol and isoprenoid GDGTs 1-3 (Słowakiewicz et al., 2016). GDGT-0 is a relatively common membrane lipid in Archaea produced by mesophilic Thaumarchaeota (Damsté et al., 2002) but also thermophilic Crenarchaeota and Euryarchaeota as well as methanogens (Koga et al., 1993) and Euryarchaeota that mediate the anaerobic oxidation of methane (Pancost et al., 2001). In microbial mats methanogens and Thaumarchaeota are, in principle, the most likely sources for GDGT-0. However, Thaumarchaeota signatures are also expected to contain relatively high amounts of crenarchaeol (Damsté et al., 2002). Consequently, Słowakiewicz et al., 2016 argued that the combination of high amounts of GDGT-0 and relative low concentrations of crenarchaeol and GDGTs 1-3 found in the samples from Qatar indicated that isoprenoidal GDGTs were produced in the mat by methanogens (Blaga et al., 2009; Słowakiewicz et al., 2016). brGDGT isomers were not detected in this study, but brGDGTs Ia, IIa, and IIIa were more abundant than crenarchaeol, and were suspected to be allochthonous to the mat.

Here, we propose to investigate whether the distribution of the different GDGT compounds is the same in different locations and whether the patterns shown in modern sabkhas are also preserved in ancient sabkhas. IODP site $1464\left(18^{\circ} 3.9115^{\prime} \mathrm{S}, 118^{\circ} 37.8935^{\prime} \mathrm{E}\right)$ is located on the Northwestern shelf of Australia in the Roebuck Basin in $270 \mathrm{~m}$ water depth (Groeneveld et al., 2017; Tagliaro et al., 2018). This site was drilled as part of IODP expedition 356. For this project, 7 samples were taken across suspected sabkha sediments from the site (Figure 2), which, according to the biostratigraphic age model, date to the Mid-Miocene, around 12-13 Ma (Groeneveld et al., 2017; Tagliaro et al., 2018). These were then compared to four Holocene sediment samples taken from a current well-studied sabkha in Abu Dhabi (Kenig et al., 1990; Alsharhan and Kendall, 2003; Bontognali et al., 2010; Strohmenger et al., 2011; Campbell et al., 2015). By comparing the two locations, we attempted to investigate the variability in the distribution of GDGTs in sabkhas from different locations and time scales and asses if there are unique signatures of GDGTs in sabkha sediments.

\section{MATERIALS AND METHODS}

Four samples were taken at three sites along a transect on the outer coastal sabkha of the Arabian Gulf, SE of Al-Rufaa Island (United Arab Emirates), previously studied by Strohmenger et al. (2011). Samples IT1 and IT2 are from a site in the modern intertidal zone, sample MS is from the modern Middle Sabkha and sample US is from the modern Upper Sabkha. At each of the three sites, we excavated a trench and sampled the buried microbial mats using $10 \mathrm{cc}$ tubes of the same kind as used onboard the JOIDES Resolution during IODP Expedition 356. Radiocarbon ages of the buried intertidal microbial mats are from Strohmenger et al. (2011), who analyzed the sedimentology, diagenesis and coastal development of the Recent to Holocene sabkha and its associated environments in this area.

In the IODP site 1464 samples, an attempt was made to take a representative number of samples from different sedimentary environments associated with suspected sabkha sediments. First, two samples [523.58 and 532.25 CSF-A (m)] were taken from dark black layers seen in the sediments (Figure 2A). Throughout the text these will be referred to as black layers. Next, two samples [535.95 and 536.12 CSFA (m)] were taken from laminated sediments below [532.25 CSF-A (m) (Figure 2B)]. These are all referred to as paleoSabkha sediments. Please see the discussion for how these were identified as such. Three more samples were taken in an interval between 552.28 and $571.2 \mathrm{~m}$ from brown, diffusively laminated wacke- to packstones (Figure 2C). These will be described as paleo-lagoonal sediments. Once again see the discussion for how these were identified as such. For each sample, 10 ccs were taken. The uppermost black layer was not lithified and was sampled with a scoop. All other samples were taken with a rock saw.

\section{GDGT Analysis and Indexes}

In order to prevent potential cross contamination, the Holocene Abu Dhabi samples and Miocene sabkha samples from Australia were freeze-dried separately. The Holocene samples were homogenized using the sampling spoon before extraction. The 
Miocene samples showed different stages of lithification. For the Miocene samples that were unlithified or poorly lithified, we used the same method as used for the Holocene samples. For the lithified Miocene sediments, the samples were ground in a mortar and pestle, which was cleaned with both DI water and DCM between uses. The Holocene and Miocene samples were then extracted using an ASE 350 extraction system. We used a new method that allows simultaneous extraction and chromatographic separation of the compounds of interest into different polarity fractions (Auderset et al., unpublished). Briefly, $16 \mathrm{~g}$ of $5 \%$ deactivated silica in Hexane were added into the extraction cell followed by $1-5 \mathrm{~g}$ of sediment. The cells were then preheated to $100^{\circ} \mathrm{C}$, filled with $34 \mathrm{~mL}$ of hexane (hex), and heated for 5 additional minutes. After this, the solvent was flushed into the collection vessel. This step was repeated three times in order to maximize extraction efficiency of each fraction. The second and third fractions were collected using the same procedure but using Dichloromethane (2nd fraction), and a mixture of Dichloromethane:Methanol (50:50) (3rd fraction) as extraction solvents. In this study, we are focusing on the results from the third fraction. Next, the samples were dried down in a rotary evaporative system, filtered through a $0.2 \mu \mathrm{m}$ PTFE filter using a $1.5 \%$ Isopropanol/Hexane mixture and analyzed by HPLC-MS using the method proposed by Hopmans et al. (2016).

In order to identify and interpret patterns in GDGT distributions we used a number of stablished GDGT indexes. The \%GDGT-0 ratio [defined as GDGT-0/(Crenarchaeol + GDGT$0)$ ] has been used to identify samples where methanogens are a significant source of GDGTs in lake systems (Blaga et al., 2009; Sinninghe Damsté et al., 2012). The Methane Index (MI) has been proposed to identify sediments dominated by gas-hydrate-related anaerobic oxidation of methane (Zhang Y.G. et al., 2011). The Ring Index (RI) is used to determine if the GDGTs fall outside of the typical distribution of the compounds in open ocean surface sediments, and therefore to identify whether they are produced by different archaeal communities (Zhang et al., 2016).

\section{Mineralogy}

Mineralogy for all samples was analyzed using x-ray diffraction. Sediment samples were dried and ground by hand, top-mounted onto a sample holder and analyzed using a Siemens D 5000 Diffractometer equipped with a $\mathrm{CuK} \alpha$ tube. All samples were scanned at $40 \mathrm{kV} / 40 \mathrm{~mA}$, from $3^{\circ}$ to $63^{\circ}$, at a scanning speed of $0.02^{\circ} / \mathrm{sec}$. Diffractograms were evaluated using the DIFFRACplus EVA software package, after baseline removal. Peak heights and I/I corundum values from the International Centre for Diffraction Data PDF database were used to measure the relative abundance of all mineral phases.

\section{RESULTS AND DISCUSSION}

\section{Sedimentology}

The thick Holocene microbial mats (samples IT1 and 2, MS, US) are known to have formed in the middle to lower intertidal zone, where they are protected from grazing organisms and have the highest preservation potential (Strohmenger et al., 2011). They

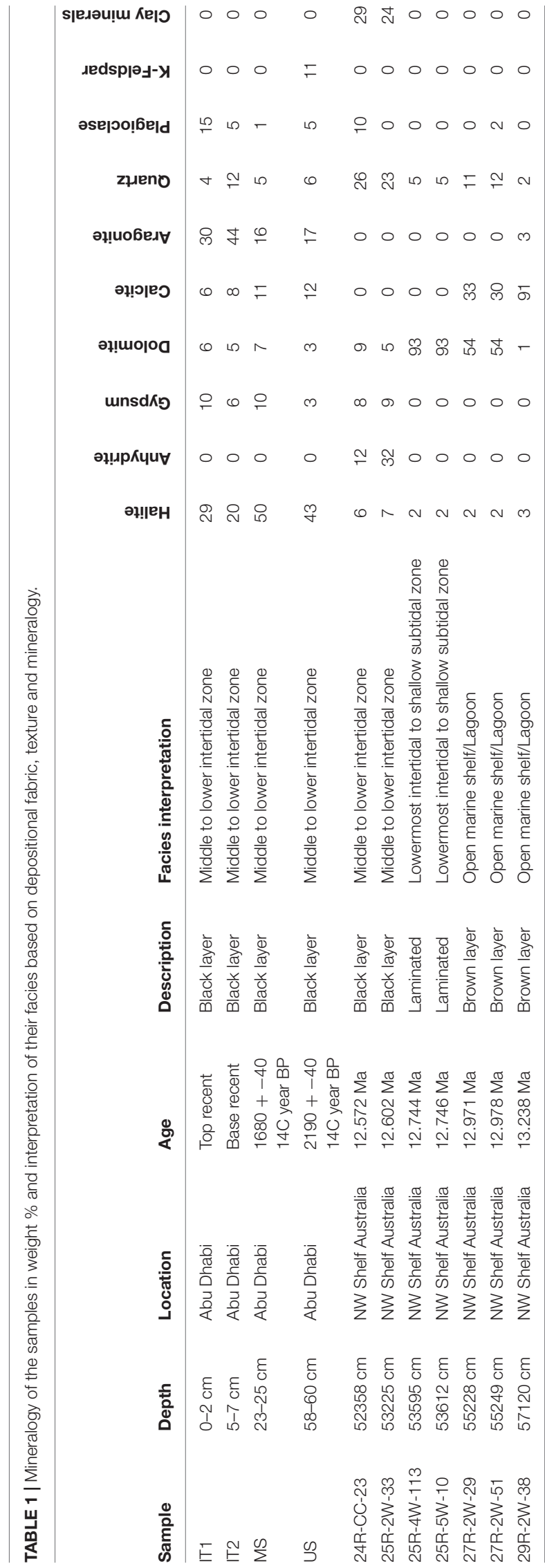


contain high amounts of halite and aragonite, with calcite, gypsum, and dolomite as subordinate phases (Table 1). Anhydrite is not present in the studied samples, but anhydrite forms an up to several $\mathrm{cm}$ thick layer at or just below the surface of the middle (Figure 1C) to upper sabkha in Abu Dhabi. Quartz and feldspars make up the siliciclastic fraction, but in combination contribute less than $20 \%$ to the mineral assemblage. The siliciclastic fraction is generally assumed to be wind-blown terrestrial input (Strohmenger et al., 2011).

The black Miocene layers (523.58 and 532.25 CSF-A (m); Figure 2A) are several centimeters thick and closely resemble the relatively thick algal mats deposited in the middle to lower intertidal zone of the modern Abu Dhabi sabkha system (Strohmenger et al., 2007, 2011; Figure 1). They are often associated with replacive nodular anhydrite with a chickenwire texture, which typically forms as a diagenetic overprint in the supratidal zone of sabkhas (Warren and Kendall, 1985; Strohmenger et al., 2011; Groeneveld et al., 2017; Tagliaro et al., 2018). The Miocene black layers contain noticeably less halite compared to their Holocene counterparts. On average, anhydrite contributes more than $20 \%$ and gypsum less than $10 \%$ to the total sediment (Figure 3). The siliciclastic fraction dominates the matrix, with quartz and clay minerals in nearly equal proportions, while plagioclase is present in only one sample. Dolomite is the only carbonate phase present and contributes less than $10 \%$. This predominance of siliciclastic matrix is in contrast to the Holocene samples. However, mixed siliciclastic-carbonate or siliciclastic dominated matrix with mainly wind sourced siliciclastics is common in many sabkhas of the Arabian/Persian Gulf (Warren, 2006). Palygorskite, the most important clay mineral in one of the Miocene samples, is also known to form an authigenic phase in microbial mats associated with sabkhas (Perri et al., 2017).

Macroscopically, the laminated Miocene sediments [535.95 and 535.95 CSF-A (m)] contain mm-thick dark laminae showing signs of erosion and sediment filled cracks (Figure 2B), possibly resulting from desiccation of algal mats. These thicker dark laminae are embedded within carbonate-mud rich sediments showing thinner, more irregular, and diffuse to crinkly laminae. Similar textures have been described from the Holocene Sabkha of Abu Dhabi (Strohmenger et al., 2010). In that study, they were interpreted as forming in the lowermost intertidal to shallow subtidal zone of low-energy microbial laminated lagoons, which would be somewhat deeper water compared to the environment of the thick black algal mat deposits described above. The laminated Miocene sediments [535.95 and 535.95 CSF-A (m)] also contain bladed anhydrite crystals several $\mathrm{cm}$ in length replacing the carbonate matrix (Figure 2B). They resemble bladed gypsum crystals that commonly are interpreted to form below the paleo-groundwater table of the supratidal zone (Warren, 1991; Strohmenger et al., 2010). The laminated Miocene sediments have a simple mineralogy consisting predominantly of dolomite mixed with low amounts of quartz (Table 1). Sulfate phases such as anhydrite or gypsum are lacking from the XRD sample but were observed as replacive phases in the core (Figure 2). The halite content is low compared to the black Miocene layers.

The Miocene samples from the interval between 552.28 and $571.2 \mathrm{~m}$ are characterized by an alternation of brown, diffusively laminated wacke- to packstones with coarser-grained lighter packstones that show moderate to common bioturbation (Figure 2C). These lighter packstones are rich in bioclasts
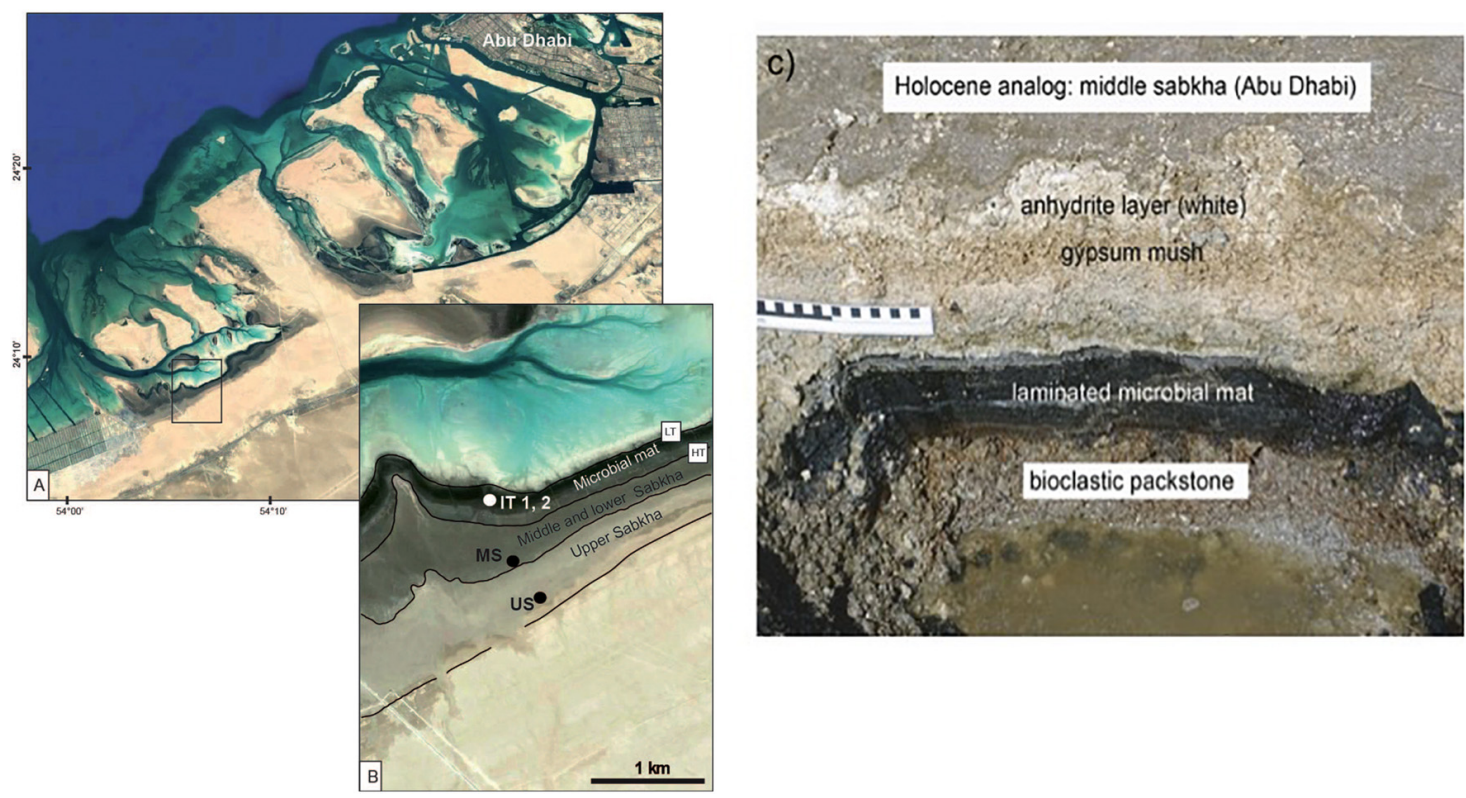

FIGURE 1 | (A) Google Earth Image (2017) of the study area at the Abu Dhabi coastline and (B) details of the sampled locations on the sabkha. Microbial mats develop in the intertidal zone between the low tide (LT) and high tide (HT) level. (C) Illustrated picture of a recent sabkha environment from Abu Dhabi sampled for this project (Sample MS) showing the distinct layers of a modern day sabkha. All the samples in the Holocene were taken from the laminated microbial mat. 


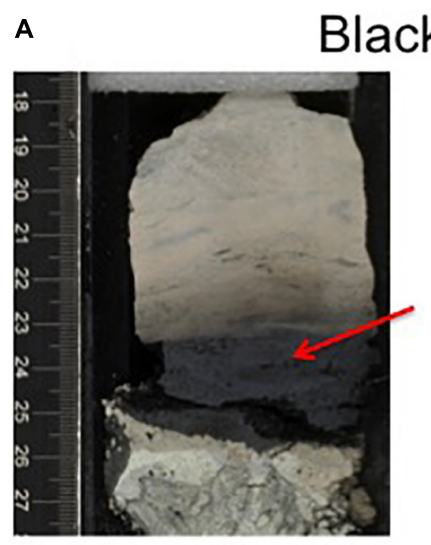

1464-24-CC

\section{ayers}

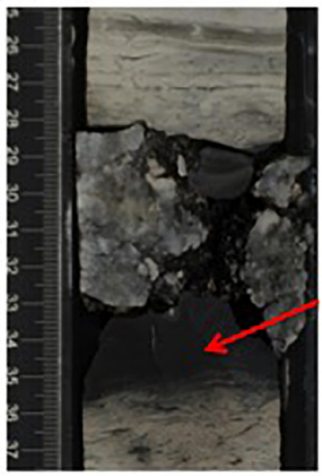

1464-25-2

B

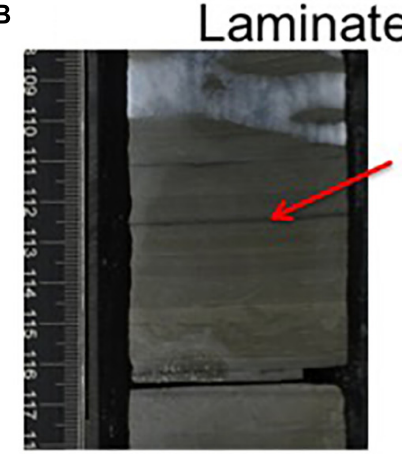

$1464-25-4$

\section{Sediment}

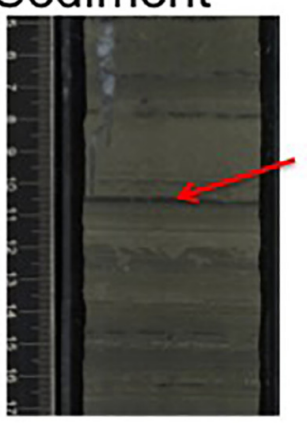

$1464-25-5$
C

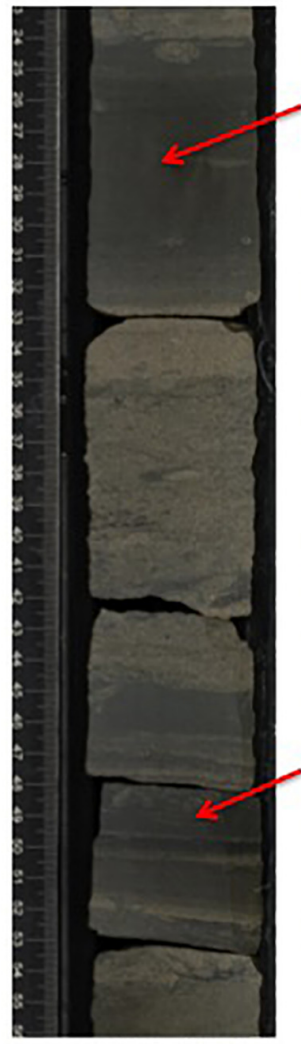

1464-27-2
Layers

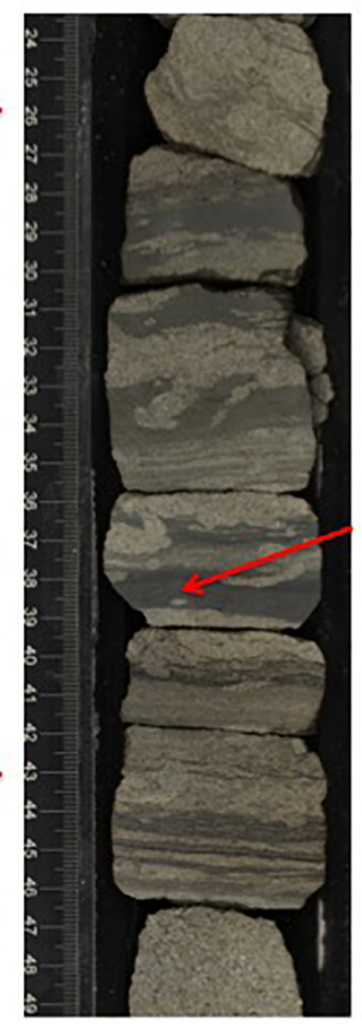

1464-29-2

FIGURE 2 | Pictures of the sampling locations for the Miocene sediments from IODP Site $1464 \mathrm{C}$ located in western Australia (1803.9244'S, $\left.118^{\circ} 37.8942^{\prime} \mathrm{E}\right)$. The $^{\circ}$ red arrows represent the location of sampling. The different sediments chosen include (A) black layers, (B) laminated sediment, and (C) brown layers.

from benthic foraminifera, echinoderms and mollusks. This alternation of lighter and darker wacke- to packstones is interpreted to have formed in an open marine environment. The occurrence of coral fragments in the same interval (356-U1464C28R-2-W 69/71-TSB-TS_175) indicates that the sediments were deposited in the photic zone of an open marine shelf or lagoon. The brown layers are dominated by carbonates but with a much higher proportion of calcite compared to the laminated Miocene sediments (Table 1). The siliciclastic phases contribute less than $15 \%$, with quartz as the dominant phase.

In summary, the black and laminated Miocene layers would be interpreted as part of a sabkha depositional system, based on sedimentological and mineralogical data. In contrast, the brown Miocene layers are interpreted to have formed in a lagoonal to open marine shelf environment.

\section{Isoprenoid GDGTs in Sabkha Samples}

Glycerol dialkyl glycerol tetraethers were found in all the sediments tested in this study, i.e., the four Holocene samples and the seven Miocene samples. In the Holocene samples, the compound GDGT-0 represents between 50 and $90 \%$ of the total GDGTs (Figure 4A). The concentration of crenarchaeol and isoprenoid GDGT compounds $1-3$ is low, comprising less than $3 \%$ of the total GDGTs in all four samples (Figure 4A). These results are consistent with the study of Słowakiewicz et al. (2016), which found similar patterns in the upper $4 \mathrm{~cm}$ of a modern microbial mat in Qatar.

The Holocene sabkha samples we analyzed show an average GDGT-0\% value of 90\% (Figure 5B). In lakes, values above 67\% in the GDGT-0\% index (i.e., GDGT-0/Crenarchaeol ratios > 2) are typically considered as being dominated by archaeal methanogenesis (Blaga et al., 2009; Sinninghe Damsté et al., 2012). This suggests that in Sabkha sediments GDGT-0 is produced by methanogenic archaea, which are known to be abundant in this environments (DiLoreto et al., 2019). The upper most (modern) Sabkha samples have MI values of 0.29 and 0.40 , respectively, which are similar to modern day open ocean sediments (Figure 5A). In contrast, in the older Holocene sediments (MS, US), the MI increases to 0.92, suggesting increasing presence of methanotrophs deeper in the sediments (Figure 5A). Regarding the RI values, as expected, all Holocene Sabkha samples fall well outside of the 2-sigma envelope of the open ocean distribution (Figure 5D). Interestingly, they all have very similar low RI values. Low values $(\sim 1.5-0.5)$ have been 


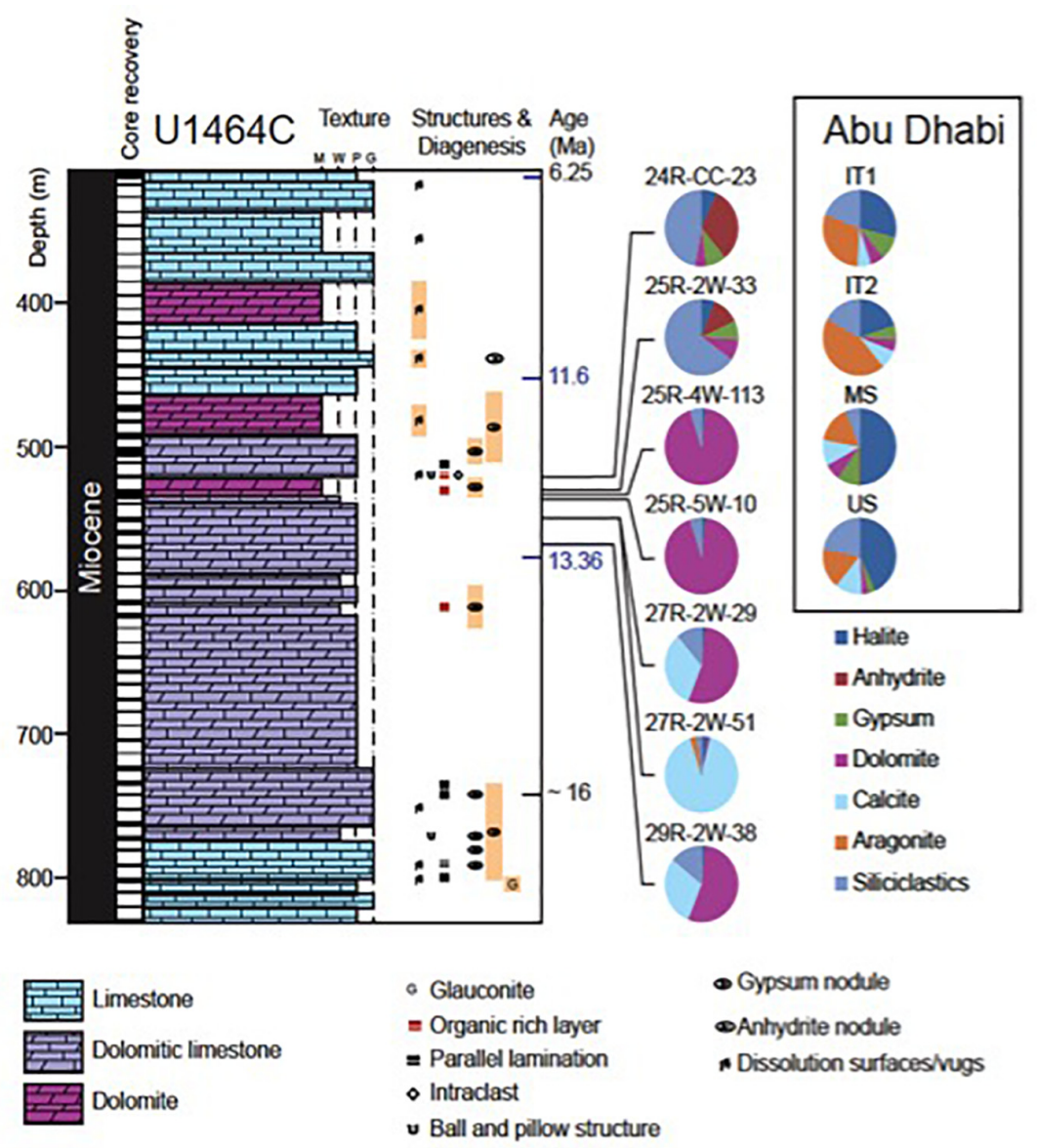

FIGURE 3 | Lithostratigraphy for Hole U1464C with biostratigraphic markers (Gallagher et al., 2017; Groeneveld et al., 2017) and comparison of mineralogy between samples from North-West Australia and Abu Dhabi.
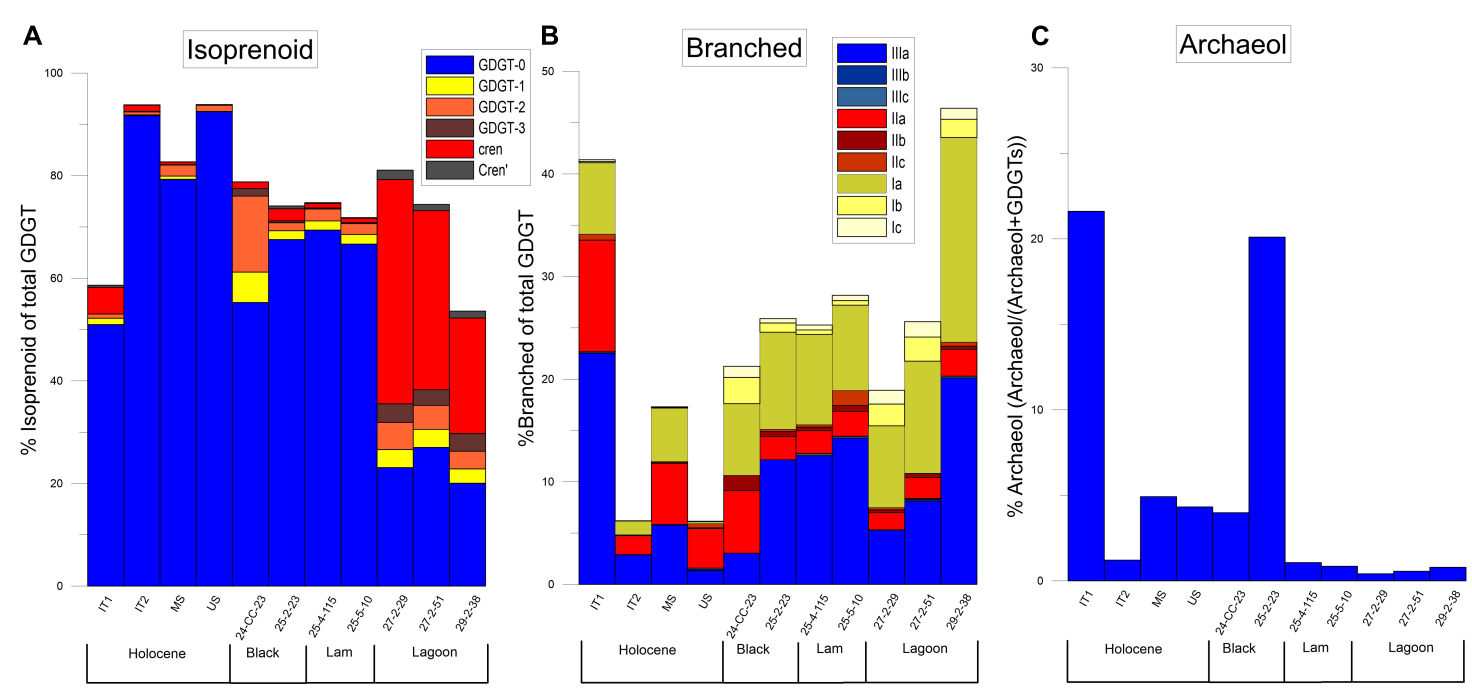

FIGURE 4 | Bar charts showing the relative amount of each GDGT compound. All compounds are shown as percent of total GDGT in sediment. (A) \%lsoprenoid. (B) \%Branched. (C) Percentage of Archeol compared to total amount of GDGT lipids. Black layers, laminated (Lam) sediments, and paleo-lagoon sediments are indicated for the Miocene samples. 

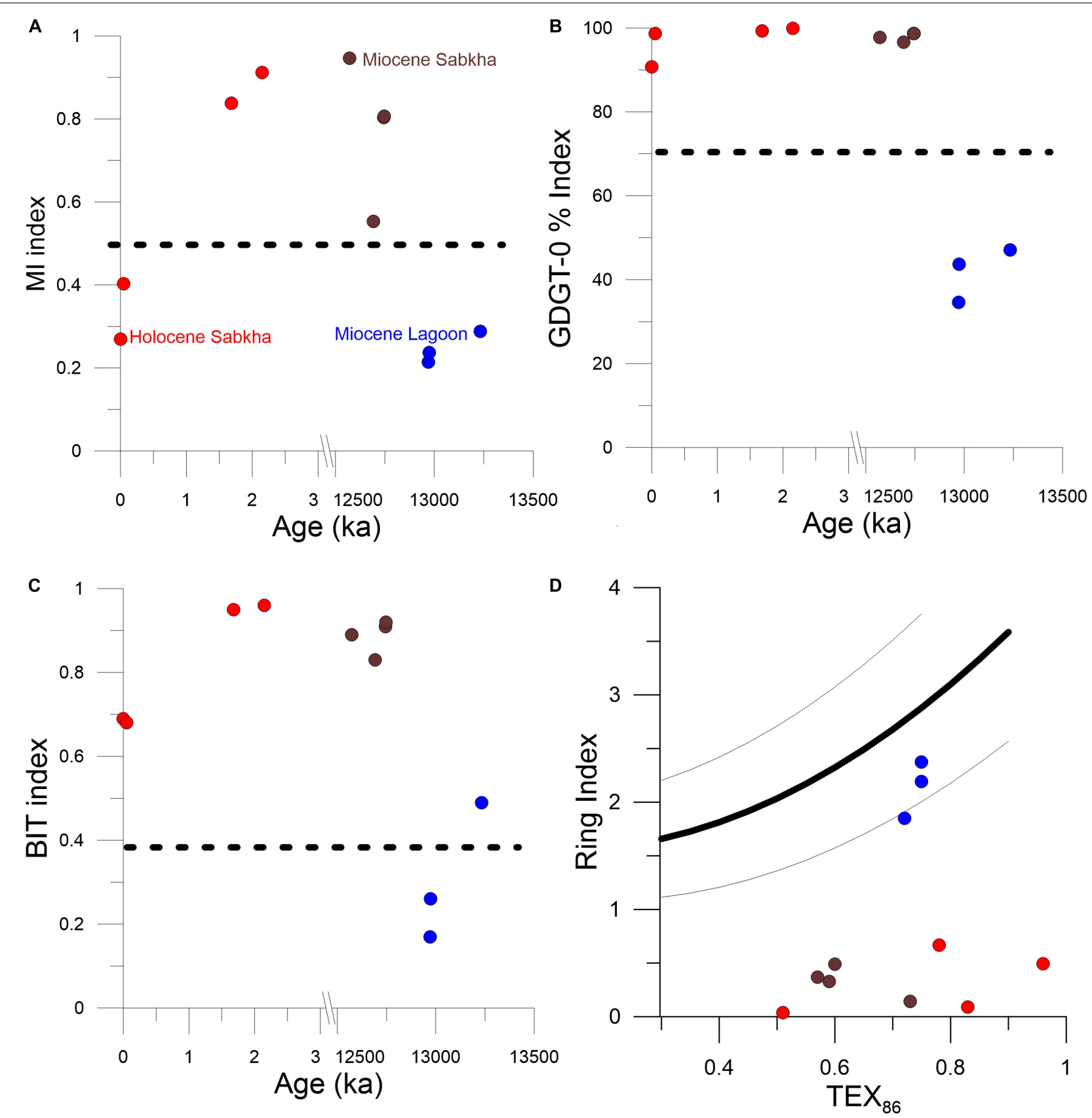

FIGURE 5 | GDGT Indexes in Sabkha and non-sabkha sediment samples. Miocene samples (brown) and Holocene (red) sabkha samples vs. Miocene non-sabkha samples (blue) (A) MI (Zhang Z. et al., 2011), (B) \% GDGT-0 (Sinninghe Damsté et al., 2012), (C) BIT (Hopmans et al., 2004), and (D) Ring Index (Zhang et al., 2016).

identified in marine sediment characterized by methanogenesis (Zhang et al., 2016), however, it should be noted that the values found here are even lower $(0.5-0)$.

The four youngest samples from the Miocene (the two black layer samples and the two laminated sediment samples) show similar GDGT-0\% to the Holocene sabkha samples. The amount of GDGT-0 represents between 55 and $61 \%$ of the total GDGTs (Figure 4A). Furthermore, the amount of crenarchaeol remains low across all four uppermost Miocene samples, with values below $2 \%$ (Figure 4A). This pattern of low crenarchaeol and high GDGT-0 found both in the Holocene and Miocene sediments appears to differ substantially from GDGTs found in other environments, such as soils, oceans, and lakes (Figure 6A). High amounts of GDGT-0 when compared to other iGDGTs have previously been seen in saline environments and methane seeps (Turich et al., 2007). In those environments, high percentages of GDGT-0 are usually coupled with high amounts of archeol (Turich and Freeman, 2011; Birgel et al., 2014; Li et al., 2016). 

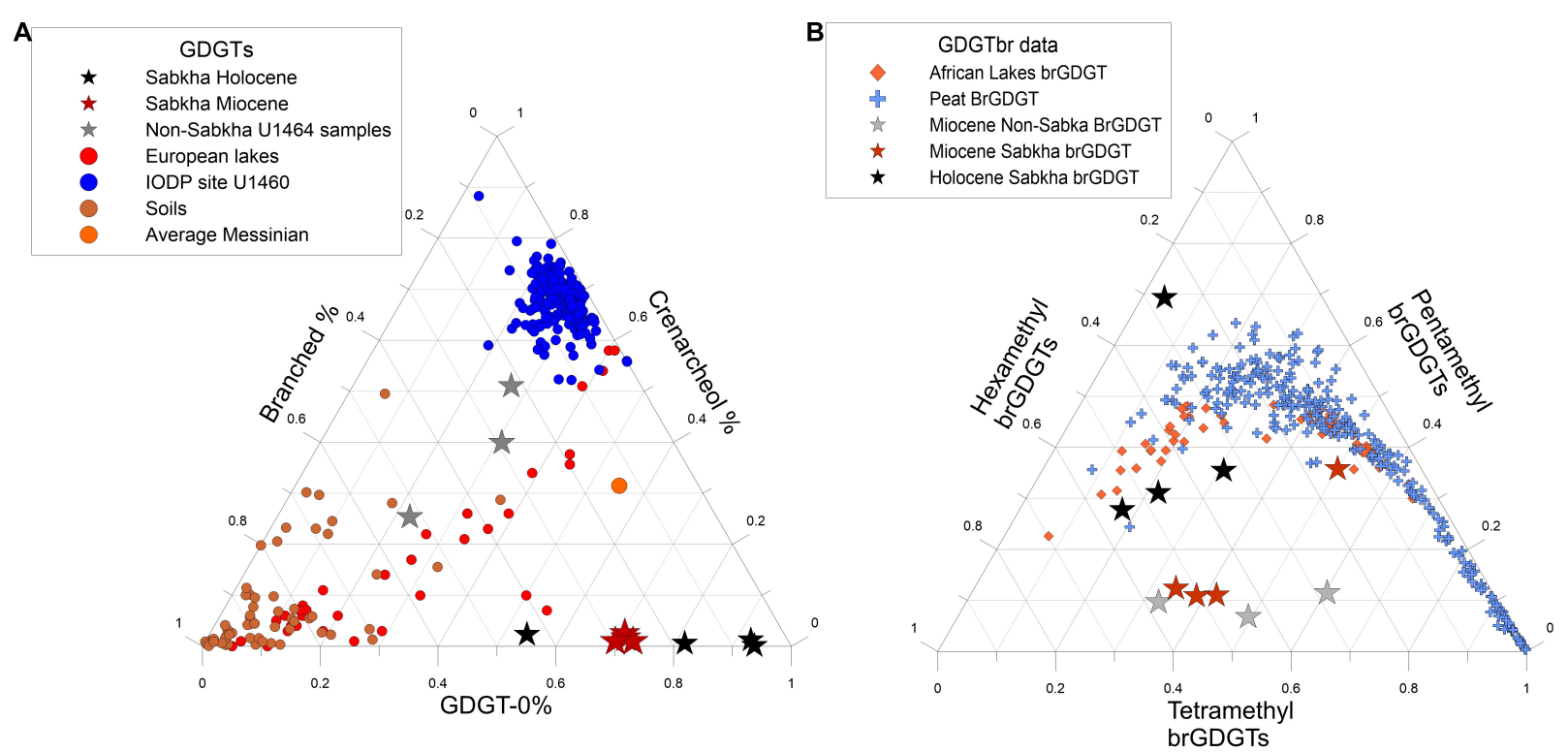

FIGURE 6 | Ternary plots showing the relationship between the various types of GDGTs. (A) Relative percentages of GDGTs in different environments. Data from: Pleistocene samples from IODP U1460, a site near by with a more oceanic signature (blue dots) (Petrick et al., 2019), European lakes (red dots) (Blaga et al., 2009), global soil sample compilation (brown dots) (Weijers et al., 2006). (B) Relative percentages of BrGDGTs in different environments including African lakes [orange diamonds (Russell et al., 2018)] and a global peat compilation [blue crosses (Naafs et al., 2017)].

With the exception of one Holocene and one Miocene sediment samples (IT1, 25-2-23), archeol is not a major component of any of the sediment we analyzed (Figure 4C). Studies suggest that while salinity may be higher than the average seawater in Sabkha environments, it varies from 40 to 150 psu (Słowakiewicz et al., 2016; DiLoreto et al., 2019). Hypersaline conditions only start at $60 \mathrm{psu}$ (Por, 1980) and previous work has shown that below 50 psu archeol levels are variable (Turich and Freeman, 2011). For this study we do not have salinity measurements for any of the sediments tested. Therefore, from such a small sample with no salinity data it is difficult to determine if the low abundance of archeol is a result of lower salinity or a distinctive component of sabkha environments.

The MI index results for Miocene sabkha samples show variability between 0.55 and 0.94 (Figure 5A). This variability may represent the difference between sediments that were subtidal, as opposed to those that were intertidal. Nevertheless, the average MI value is 0.77 , which suggests a high amount of methane utilization (Figure 5A). The Miocene RI index has an average value of 0.33 , similar to the Holocene Sabkhas. The similarity of the two values might indicate that this is a typical value for this kind of sediments. In contrast, nonsabkha Miocene sediments taken from the brown layers below the suspected Miocene sabkha sediments show low GDGT-0\%, low MI, relatively high crenarchaeol concentrations, and RI values in the range of modern open ocean sediments (Figures 5D, 6). This shows that it is possible to distinguish paleo-sabkha sediments from sediments deposited in open marine settings based on their respective GDGT distributions.

We suggest that the combination of high GDGT-0, low crenarchaeol, high MI, and extremely low RI may be a defining feature of the microbial mats from Sabkhas. The similarity of iGDGT distributions between the mid-Miocene and the Holocene sabkhas indicate that these characteristic signatures are preserved in the geologic record.

\section{Branched GDGTs in Sabkha Sediments}

The brGDGT in the Holocene sabkhas make up between 10 and $45 \%$ of the total GDGTs (Figure $4 B$ ). The brGDGT relative abundances are different at different depths. In the upper two samples, the hexamethyl (III) brGDGTs are most abundant, followed by the pentamethyl (II) compounds. However, in the two Holocene samples, this is reversed (Figure 4B). The reason for this difference is unclear. We note that the Holocene samples fall slightly below the normal range for modern terrestrial and semi-terrestrial biomarkers (Figure 6B). In addition, the relative amounts of brGDGTs in the Holocene samples do not correlate with the silicate XRD record of terrestrial input in the same samples.

The BIT index has traditionally been used to track the amount of "terrestrial organic input" in a given sample. However, the BIT index provides only a rough measurement of whether brGDGTs dominate the overall GDGT components of a sample. In the BIT index, any result above 0.30 is considered influenced by terrestrial organic input (Hopmans et al., 2004; Weijers et al., 2006; Sinninghe Damsté et al., 2012; Woltering et al., 2012). The BIT index average for the Holocene samples is 0.80 , which, using the traditional interpretation, would mean that the brGDGTs are transported to the microbial mat from soils (Figure 5C). However, because of the dominance of methane producing GDGTs in the sediment crenarchaeol abundances are remarkably low. Therefore, as it has been previously suggested for other 
environmental settings (Fietz et al., 2011; Xiao et al., 2016), the high BIT values are driven by the low abundance of crenarchaeol rather than by the abundance of brGDGTs. For example, with the exception of the IT1 sample, the modern sabkha samples have the lowest relative amount of brGDGTs of all of the samples although they have some of the highest BIT values (Figure 5C). This indicates that in Sabkha environments the BIT index is not a valid measure for the amount of terrestrial organic input.

The brGDGTs present a complex pattern in the Upper 4 Miocene samples. The overall proportion of brGDGTs is more consistent than that found in the Holocene sediments, with brGDGTs making up about 25\% of both the black layers and the laminated sediments (Figure 4B). As in the Holocene, this data does not correspond to the records of terrestrial input derived from the XRD data, which shows, particularly in the black layers, a much higher proportion of terrestrial sediments than in any of the other Miocene sample. Finally, the BIT index is always above 0.9 much like in the modern sediments (Figure 5C).

However, unlike the Holocene samples, tetramethyl (I) and hexamethyl (III) compounds dominate in the Miocene layers, with relatively lower abundances of Pentamethyl (II) compounds (Figure 6B). These samples also have different percentages of the various brGDGT compounds than other similar environments, such as peats and lakes (Figure 6B). However, the samples from the brown layers below the laminated layers, which are not from a sabkha environment, fall on the same part of the ternary diagram as the sabkha sediments above (Figure 6B), suggesting a similar environment of production. In addition, the brGDGTs in all of the Miocene sediments are dominated by Ia, IIa, and IIIa with little of the b and $c$ compounds in each group (Figure 6B).

Given these unusual distributions the question is if the brGDGTs are produced in the sediment in situ or are they transported from elsewhere. Based on the information now available this is not clear. The differences in the pattern of brGDGTs in the Miocene and Holocene Sabkhas suggest different sources at the two sites. Furthermore, the fact that the paleo-sabkha Miocene sediments have a similar pattern to the paleo-lagoonal sediments suggesting that they came from similar sources of brGDGT despite of the different depositional environment (Figure 6B). This suggests that independently of whether these compounds are produced in situ or not, they are not diagnostic of paleo-sabkha environments. Unusual distributions of brGDGTs with high amounts of Ia and IIa were identified in a previous study in coal and other samples characterized by high amounts of kerogen (Weijers et al., 2011). The authors of this study suggested that this might have been a result of degradation of brGDGT during the transition to kerogen in organic rich sediments. It cannot be discarded that the pattern observed in the Miocene Sabkha and paleo-lagoonal sediments is a result of degradation of brGDGTs and transport from mature sources of organic matter. In any case, it is clear that further work is required to identify the source and significance of brGDGTs in sabkha environments.

\section{CONCLUSION}

In this study, we have shown that the Miocene sediments from IODP site 1464 are likely the remains of a Miocene Sabkha. When comparing these sediments to more recent Holocene sabkhas, we confirm that sabkha associated microbial mats have a distinctive pattern of isoprenoid GDGTs characterized by high \%GDGT-0 and MI, and an unusual distribution of isoprenoid GDGTs 1-3 that results in extremely low RI values. Our results indicate that this distinct pattern of GDGTs is preserved through the geological record, not only in Holocene sediments, but in older Miocene sediments as well. Therefore, although further work is required for a complete characterization of these environments, our data indicate that GDGTs can be used in combination with facies analysis to identify microbial mats from paleoSabkha sediments.

\section{DATA AVAILABILITY STATEMENT}

The datasets generated for this study are available on request to the corresponding author.

\section{AUTHOR CONTRIBUTIONS}

BP and LR designed the study. BP performed the analysis of GDGTs in the lab of AM-G at the Max Planck Institute for Chemistry (MPIC). LR preformed the sedimentology analysis and XRD at Aachen University. All authors contributed to the final version of the manuscript.

\section{FUNDING}

This study was funded by the Max Planck Society to BP and AM-G, and by the DFG (German Science Foundation, Project 320220579) to LR. All the data from this article will be publicly available in the PANGEA database.

\section{ACKNOWLEDGMENTS}

The IODP provided the sediments and we would like to thank the scientists and crew of the Joides Resolution and Expedition 356. We would like to thank Jörg Smodej for help during sampling. We would also thank Uwe Wollenberg for his help with XRD measurements. Thanks to Florian Rubach, Barbara Hinnenberg and Alex Auderset for their help with the analysis of GDGTs. Discussion with Christian Strohmenger and Karolin Sparwasser significantly improved the manuscript. Finally, we would like to thank the editor and two reviewers whose feedback also improved the manuscript. 


\section{REFERENCES}

Alsharhan, A. S., and Kendall, C. G. S. C. (2003). Holocene coastal carbonates and evaporites of the southern arabian gulf and their ancient analogues. Earth Sci. Rev. 61, 191-243. doi: 10.1016/s0012-8252(02)00110-1

Birgel, D., Guido, A., Liu, X., Hinrichs, K.-U., Gier, S., and Peckmann, J. (2014). Hypersaline conditions during deposition of the calcare di base revealed from archaeal di- and tetraether inventories. Org. Geochem. 77, 11-21. doi: 10.1016/ j.orggeochem.2014.09.002

Blaga, C. I., Reichart, G.-J., Heiri, O., and Sinninghe Damsté, J. S. (2009). Tetraether membrane lipid distributions in water-column particulate matter and sediments: a study of 47 European lakes along a north-south transect. J. Paleolimnol. 41, 523-540. doi: 10.1007/s10933-008-9242-2

Bontognali, T. R. R., Vasconcelos, C., Warthmann, R. J., Bernasconi, S. M., Dupraz, C., Strohmenger, C. J., et al. (2010). Dolomite formation within microbial mats in the coastal sabkha of Abu Dhabi (United Arab Emirates). Sedimentology 57, 824-844. doi: 10.1111/j.1365-3091.2009.01121.x

Campbell, J. E., Lacey, E. A., Decker, R. A., Crooks, S., and Fourqurean, J. W. (2015). Carbon storage in seagrass beds of Abu Dhabi. United Arab Emirates. Estuaries Coasts 38, 242-251. doi: 10.1007/s12237-014-9802-9

Chan, M. A., Nicoll, K., Ormö, J., Okubo, C., and Komatsu, G. (2011). "Utah's geologic and geomorphic analogs to Mars-An overview for planetary exploration," in Analogs for Planetary Exploration, eds W. B. Garry, and J. E. Bleacher, (Utah, UT: USGS Publication Warehouse), 349-375. doi: 10.1130/ 2011.2483(22)

Curtis, R., Evans, G., Kinsman, D. J. J., and Shearman, D. J. (1963). Association of dolomite and anhydrite in the recent sediments of the persian gulf. Nature 197, 679-680. doi: 10.1038/197679a0

Damsté, J. S. S., Schouten, S., Hopmans, E. C., van Duin, A. C. T., and Geenevasen, J. A. J. (2002). Crenarchaeol: the characteristic core glycerol dibiphytanyl glycerol tetraether membrane lipid of cosmopolitan pelagic crenarchaeota. J. Lipid Res. 43, 1641-1651. doi: 10.1194/jlr.m200148-jlr200

Davies, G. R. (1970). Algal-laminated sediments. gladstone embayment, shark bay, Western Australia. Am. Assoc. Petrol. Geol. Mem. 13, 169-205.

DiLoreto, Z. A., Bontognali, T. R. R., Al Disi, Z. A., Al-Kuwari, H. A. S., Williford, K. H., Strohmenger, C. J., et al. (2019). Microbial community composition and dolomite formation in the hypersaline microbial mats of the khor aladaid sabkhas. qatar. Extremophiles 23, 201-218. doi: 10.1007/s00792-01801074-4

Edwards, H. G. M., Sadooni, F., Vítek, P., and Jehlicka, J. (2010). Raman spectroscopy of the dukhan sabkha: identification of geological and biogeological molecules in an extreme environment. Philos. Trans. Ser. A Math. Phys. Eng. Sci. 368, 3099-3107. doi: 10.1098/rsta.2010.0101

Evans, G., Schmidt, V., Bush, P., and Nelson, H. (1969). Stratigraphy and geologic history of the sabkha, Abu Dhabi, persian gulf. Sedimentology 12, 145-159. doi: 10.1111/j.1365-3091.1969.tb00167.x

Fietz, S., Martínez-Garcia, A., Huguet, C., Rueda, G., and Rosell-Melé, A. (2011). Constraints in the application of the branched and isoprenoid tetraether index as a terrestrial input proxy. J. Geophys. Res. 116:C10032.

Gallagher, S. J., Fulthorpe, C. S., Bogus, K., Auer, G., Baranwal, S., Castañeda, I. S., et al. (2017). "Expedition 356 of the riserless drilling platform," in Proceedings of the International Ocean Discovery Program (Fremantle: International Ocean Discovery Program).

Groeneveld, J., Henderiks, J., Renema, W., McHugh, C. M., De Vleeschouwer, D., Christensen, B. A., et al. (2017). Australian shelf sediments reveal shifts in miocene Southern hemisphere westerlies. Sci. Adv. 3:e1602567. doi: 10.1126/ sciadv. 1602567

Hopmans, E. C., Schouten, S., and Sinninghe Damsté, J. S. (2016). The effect of improved chromatography on GDGT-based palaeoproxies. Org. Geochem. 93, 1-6. doi: 10.1016/j.orggeochem.2015.12.006

Hopmans, E. C., Weijers, J. W. H., Schefuss, E., Herfort, L., Damste, J. S. S., Schouten, S., et al. (2004). A novel proxy for terrestrial organic matter in sediments based on branched and isoprenoid tetraether lipids. Earth Planet. Sci. Lett. 224, 107-116. doi: 10.1016/j.epsl.2004.05.012

Kenig, F., Huc, A. Y., Purser, B. H., and Oudin, J.-L. (1990). Sedimentation, distribution and diagenesis of organic matter in a recent carbonate environment, Abu Dhabi, U.A.E. Org. Geochem. 16, 735-747. doi: 10.1016/ 0146-6380(90)90113-e
Koga, Y., Nishihara, M., Morii, H., and Akagawa-Matsushita, M. (1993). Ether polar lipids of methanogenic bacteria: structures, comparative aspects, and biosyntheses. Microbiol. Rev. 57, 164-182.

Li, J., Pancost, R. D., Naafs, B. D. A., Yang, H., Zhao, C., and Xie, S. (2016). Distribution of glycerol dialkyl glycerol tetraether (GDGT) lipids in a hypersaline lake system. Org. Geochem. 99, 113-124. doi: 10.1016/j. orggeochem.2016.06.007

Lugli, S., Manzi, V., Roveri, M., and Schreiber, B. C. (2015). The deep record of the messinian salinity crisis: evidence of a non-desiccated mediterranean sea. Palaeogeogr. Palaeoclimatol. Palaeoecol. 433, 201-218. doi: 10.1016/j.palaeo. 2015.05.017

Maliński, E., Gạsiewicz, A., Witkowski, A., Szafranek, J., Pihlaja, K., Oksman, P., et al. (2009). Biomarker features of sabkha-associated microbialites from the zechstein platy dolomite (Upper Permian) of northern poland. Palaeogeogr. Palaeoclimatol. Palaeoecol. 273, 92-101. doi: 10.1016/j.palaeo.2008.12.005

Naafs, B. D. A., Inglis, G. N., Zheng, Y., Amesbury, M. J., Biester, H., Bindler, R., et al. (2017). Introducing global peat-specific temperature and $\mathrm{pH}$ calibrations based on brGDGT bacterial lipids. Geochim. Cosmochim. Acta 208, 285-301. doi: 10.1016/j.gca.2017.01.038

Pancost, R., Hopmans, E., and Sinninghe Damsté, J. (2001). Archaeal lipids in mediterranean cold seeps: molecular proxies for anaerobic methane oxidation. Geochim. Cosmochim. Acta 65, 1611-1627. doi: 10.1016/s0016-7037(00) 00562-7

Perri, E., Tucker, M. E., Słowakiewicz, M., Whitaker, F., Bowen, L., and Perrotta, I. D. (2017). Carbonate and silicate biomineralization in a hypersaline microbial mat (Mesaieed sabkha, Qatar): roles of bacteria, extracellular polymeric substances and viruses. Sedimentology 65, 1213-1245. doi: 10.1111/ sed.12419

Petrick, B., Martínez-García, A., Auer, G., Reuning, L., Auderset, A., Deik, H., et al. (2019). Glacial indonesian throughflow weakening across the mid-pleistocene climatic transition. Sci. Rep. 9:16995. doi: 10.1038/s41598-019-53382-0

Por, F. D. (1980). A classification of hypersaline waters, based on trophic criteria. Mar. Ecol. 1, 121-131. doi: 10.1111/j.1439-0485.1980.tb00214.x

Russell, J. M., Hopmans, E. C., Loomis, S. E., Liang, J., and Sinninghe Damsté, J. S. (2018). Distributions of 5- and 6-methyl branched glycerol dialkyl glycerol tetraethers (brGDGTs) in east african lake sediment: effects of temperature, ph, and new lacustrine paleotemperature calibrations. Org. Geochem. 117, 56-69. doi: 10.1016/j.orggeochem.2017.12.003

Schouten, S., Hopmans, E. C., and Sinninghe Damsté, J. S. (2013). The organic geochemistry of glycerol dialkyl glycerol tetraether lipids: a review. Org. Geochem. 54, 19-61. doi: 10.1016/j.orggeochem.2012.09.006

Sinninghe Damsté, J. S., Ossebaar, J., Schouten, S., and Verschuren, D. (2012). Distribution of tetraether lipids in the 25-ka sedimentary record of lake challa: extracting reliable TEX86 and MBT/CBT palaeotemperatures from an equatorial African lake. Quat. Sci. Rev. 50, 43-54. doi: 10.1016/j.quascirev.2012. 07.001

Słowakiewicz, M., Whitaker, F., Thomas, L., Tucker, M. E., Zheng, Y., Gedl, P., et al. (2016). Biogeochemistry of intertidal microbial mats from qatar: new insights from organic matter characterisation. Org. Geochem. 102, 14-29. doi: 10.1016/j.orggeochem.2016.09.006

Strohmenger, C. J., Al-Mansoori, A., Al-Jeelani, O., Al-Hosani, I., Al-Shamry, A., Al-Baker, S., et al. (2011). "Facies stacking patterns in a modern arid environment: a case study of the abu dhabi sabkha in the vicinity of alqanatir island, united arab emirates," in Quaternary Carbonate and Evaporite Sedimentary Facies and Their Ancient Analogues, eds A. Alsharhan, and C. C. G. KendallSt, (International Association of Sedimentologists, Special Publication), $149 \mathrm{e} 182$.

Strohmenger, C. J., Al-Mansoori, A., Al-Jeelani, O., Al-Shamry, A., Al-Hosani, I., Al-Mehsin, K., et al. (2010). The sabkha sequence at mussafah channel (Abu Dhabi, United Arab Emirates): facies stacking patterns, microbial-mediated dolomite and evaporite overprint. GeoArabia 15, 49-90.

Strohmenger, C. J., Shebl, H., Al-Mansoori, A., Al-Mehsin, K., Al-Jeelani, O., AlHosani, I., et al. (2007). Depositional environment and sea-level history of the Abu Dhabi sabkha in the vicinity of al-qanatir island. united arab emiratese. GeoArabia 12:219.

Suosaari, E. P., Reid, R. P., Playford, P. E., Foster, J. S., Stolz, J. F., Casaburi, G., et al. (2016). New multi-scale perspectives on the stromatolites of shark bay, western australia. Sci. Rep. 6:20557. doi: 10.1038/srep20557 
Tagliaro, G., Fulthorpe, C. S., Gallagher, S. J., McHugh, C. M., Kominz, M., and Lavier, L. L. (2018). Neogene siliciclastic deposition and climate variability on a carbonate margin: australian northwest shelf. Mar. Geol. 403, 285-300. doi: 10.1016/j.margeo.2018.06.007

Turich, C., and Freeman, K. H. (2011). Archaeal lipids record paleosalinity in hypersaline systems. Org. Geochem. 42, 1147-1157.

Turich, C., Freeman, K. H., Bruns, M. A., Conte, M., Jones, A. D., and Wakeham, S. G. (2007). Lipids of marine archaea: patterns and provenance in the watercolumn and sediments. Geochim. Cosmochim. Acta 71, 3272-3291. doi: 10. 1016/j.gca.2007.04.013

Warren, J. K. (1991). "Sulfate dominated sea-marginal and platform evaporative settings," in Evaporites, Petroleum and Mineral Resources, Developments in Sedimentology, Vol. 50, ed. J. L. Melvin (Amsterdam: Elsevier), 477-533.

Warren, J. K. (2006). Evaporites: Sediments, Resources, and Hydrocarbons. Berlin: Springer.

Warren, J. K., and Kendall, C. G. S. C. (1985). Comparison of sequences formed in marine sabkha (subarial) and salina (subaqueous) settings - modern and ancient. Am. Assoc. Pet. Geol. Bull. 69, 1013-1023.

Weijers, J. W. H., Schouten, S., Spaargaren, O. C., and Sinninghe Damsté, J. S. (2006). Occurrence and distribution of tetraether membrane lipids in soils: implications for the use of the TEX86 proxy and the BIT index. Org. Geochem. 37, 1680-1693. doi: 10.1016/j.orggeochem.2006. 07.018

Weijers, J. W. H., Steinmann, P., Hopmans, E. C., Schouten, S., and Sinninghe Damsté, J. S. (2011). Bacterial tetraether membrane lipids in peat and coal: testing the MBT-CBT temperature proxy for climate reconstruction. Org. Geochem. 42, 477-486. doi: 10.1016/j.orggeochem.2011. 03.013

Woltering, M., Werne, J. P., Kish, J. L., Hicks, R., Sinninghe Damsté, J. S., and Schouten, S. (2012). Vertical and temporal variability in concentration and distribution of thaumarchaeotal tetraether lipids in lake superior and the implications for the application of the TEX86 temperature proxy. Geochim. Cosmochim. Acta 87, 136-153. doi: 10.1016/j.gca.2012.03.024

Wood, G. V., and Wolfe, M. J. (1969). Sabkha cycles in the arab/darb formation off the trucial coast of arabia. Sedimentology 12, 165-191. doi: 10.1111/j.13653091.1969.tb00873.x

Xiao, W., Wang, Y., Zhou, S., Hu, L., Yang, H., and Xu, Y. (2016). Ubiquitous production of branched glycerol dialkyl glycerol tetraethers (brGDGTs) in global marine environments: a new source indicator for brGDGTs. Biogeosciences 13, 5883-5894. doi: 10.5194/bg-13-5883-2016

Zhang, Y. G., Pagani, M., and Wang, Z. (2016). Ring index: a new strategy to evaluate the integrity of TEX 86 paleothermometry. Paleoceanography 31 , 220-232. doi: 10.1002/2015pa002848

Zhang, Y. G., Zhang, C. L., Liu, X.-L., Li, L., Hinrichs, K.-U., and Noakes, J. E. (2011). Methane index: a tetraether archaeal lipid biomarker indicator for detecting the instability of marine gas hydrates. Earth Planet. Sci. Lett. 307, 525-534. doi: 10.1016/j.epsl.2011.05.031

Zhang, Z., Nisancioglu, K. H., Flatøy, F., Bentsen, M., Bethke, I., and Wang, H. (2011). Tropical seaways played a more important role than high latitude seaways in cenozoic cooling. Clim. Past 7, 801-813. doi: 10.5194/cp-7-8012011

Conflict of Interest: The authors declare that the research was conducted in the absence of any commercial or financial relationships that could be construed as a potential conflict of interest.

Copyright (c) 2019 Petrick, Reuning and Martínez-García. This is an open-access article distributed under the terms of the Creative Commons Attribution License (CC BY). The use, distribution or reproduction in other forums is permitted, provided the original author(s) and the copyright owner(s) are credited and that the original publication in this journal is cited, in accordance with accepted academic practice. No use, distribution or reproduction is permitted which does not comply with these terms. 